\title{
Can Latin America Move Forward after a Lost Decade in Technical Change? ... Looking at Opportunities for Knowledge-based Change in Times of Increasing Uncertainty
}

\author{
Manuel Heitor', Hugo Horta ${ }^{1,2}$, Rosario Castañón ${ }^{3}$, Roberto Sbragia ${ }^{4}$,Alejandro Jiménez ${ }^{5}$
}

\begin{abstract}
In view of the current global context, which challenges are facing science- and technology-based developments and cooperation in a way to contribute for policies that stimulate localized learning, innovation and endogenous development in Latin America?

This broad question has motivated the work behind the Special Issue introduced by this paper, which considers the development of case studies in selected Latin America regions. The analysis lead us to argue that value-based networks have the potential to make both public policies and markets more effective, promoting learning trajectories for the inclusive development of regions. But they require effective public investments to keep attracting and qualifying human resources, together with long-term developments towards technical industries and export capacity for emerging markets worldwide. Our analysis argues about the unique potential for further developing Latin America through strategic international, knowledge-based ventures, exploring the emerging role the internationalization of universities and scientific institutions may play at a global level. Above all, they require the systematic observation of science and technical change in international comparison, as well as a relational infrastructure for collective action, at an international level, in a context much influenced by a dynamic of change and a necessary balance between the creation and diffusion of knowledge towards the endogenous development of all parts involved. The role of Latin America Universities and science policies based on international cooperation are considered to be particularly important in this process.
\end{abstract}

Keywords: technical change; innovation policy; Latin America; science policies; international cooperation; special issue

\footnotetext{
I Center for Innovation, Technology and Policy Research, IN+, Instituto Superior Técnico, University of Lisbon, Portugal.

2 University of Hong Kong, SAR, China.

${ }^{3}$ Centro de Ciencias Aplicadas y Desarrollo Tecnológico, UNAM, México.

${ }^{4}$ Center for Technology Management and Policy, PGT; School of Economics and Management, FEA, University of São Paulo, USP, Brazil.

${ }^{5}$ School of Economics and Business, Universidad Alberto Hurtado, Chile.
} 


\section{Introduction: research framework and hypothesis}

In this paper we forward ideas to contribute to the development of modern systems of technical change in Latin America, with particular attention to new developments in emerging societies and developing regions. The basic premise of this paper is that the central locus of innovation has increasingly become distributed and increasingly dependent upon linkages between many different institutions and sources of knowledge worldwide. First, the increasingly transnational business, technology and science require evolving from nationalistic approaches to new collaborative policy frameworks. Among these, large international collaborative arrangements play an emerging role. Second, the science and technology performance sectors, namely government, industry and academia, remain key players, but the connectivity, links and associations with other institutional players and agencies are no less important. In particular, the increasingly relevant role played by new technology-based firms is identified which are also becoming global. This requires strengthening science and innovation policies, promoting investments in R\&D, involving multiple public and private agents and stimulating global research networks towards socio-economic resilience and active learning mechanisms worldwide.

These questions are gaining increasing relevance as much of the political debate worldwide is centered on economic competiveness in the long term, most of the times under a rather "nationalistic" approach to innovation for growth (see, for exemple, McKinsey Global Institute, 2012; Mazzucato, 2013). The question that does arises is if the acceleration of knowledge investments in China and the impact of the international context in the US and EU, with the notable exception of Germany, should be countered by aggressive "techno-nationalism" elsewhere?

Any new narrative on global research networks requires the analyses of, at least, the last decades and the seminal work of Sylvia Ostry and Dick Nelson (1995), who among many others for the last twenty years, have called for our attention on the relationship between the globalism of firms and the nationalism of governments, as well as the related interplay of cooperation and competition that characterizes high technology and knowledge-based environments.

It should be noted that the Brookings Institution's project described by Ostry and Nelson (1995) of the early 90's has promoted this debate, although in a different international context, and it has clearly shown that tensions about deeper integration arise from three broad sources: cross-border spillovers, diminished national autonomy, and challenges to political sovereignty. As a result, the technoglobalism of the 80 's gave rise to national policies designed to help high-tech industries become more innovative and, consequently, the emergence of technonationalism.
It is under this context that the concept of "national systems of innovation" emerged in academia, mainly through economists and related schools of thought, to explain and explore how and why the systems have evolved differently in the major industrial nations, mainly US, Japan, UK, Germany and France. It was clear by then that the increasing international tensions and economic instability (see, for example Galbraith, 2012; Easterly, 2013) were largely a result of the attempt of governments to impose implement? national technology and innovation policies in a world in which business and technology are increasingly transnational.

It is in this context that this paper and the remaining papers in this Special Issue contribute to address challenges and opportunities for modernizing technical change in Latin America in coming years. It was written having in mind the unique opportunities many regions worldwide are facing to develop new and modern universities (Mazzucato, 20l3). The key role for policy makers and governments, in those regions where new investments are being made, is to select priority actions and make the correct decisions: where and how to start the process?

For the purposes of this paper, we use international comparisons but draw also from field ork conducted over the last few years in Latin America, as well as our selfexperience as researchers and policymakers in the field of technology management and innovation policy. The work is also based on some papers presented during a major event organized by some of the authors in Porto, Portugal, in October 2013 bringing together over 800 experts in science, technology and innovation policies in Latin America (ALTEC 20I3, http://www.altec2013.org/).

It should also be noted that this paper and the Special Issue are not intended to provide any type of recipe. Rather, they aim to launch a new agenda for research in technology management and innovation, based on lessons learned. We attempt to explore the dynamic relationship between economy and knowledge production and consider the social construction of technological systems, as seminally described by Bijker et al. (1987). Following the message of Conceição and Heitor (2002) and Nowotny et al (2003), in that "science is contextualized", we foster the idea that knowledge diffusion processes, and therefore innovation, are "context-sensitive" and should be pursued towards "inclusive learning". In other words, any region worldwide has to learn its own way and build its own development path. Certainly, it is also relevant to continuously adapting and improving lessons learned from others. 
This introductory paper of the Special Issue draws main implications of our research framework for new science and technology policies in Latin America in times of increasing uncertainty and on the rise of globalization. We start by discussing, in the next section, the context for technical change in the 2000's and the relative positioning of Latin America at a world level. Section 3 briefly presents our conceptual framework, by discussing the need to evolve from the "old" paradigm of "national systems of innovation", which is rather limitative on addressing emerging patterns of openness and international cooperation. We discuss, in particular, the need to strengthen main pillars of research and education, together with an industrial base for socio-economic resilience in articulation with diversified stakeholders. Then, in Section 4, we focus our analysis in terms of main implications for science and innovation policies in Latin America, including critical issues of internationalizing the knowledge base and the increasingly important role played by new technology based firms. Section 5 discusses the necessary cultural dimension, and addresses the critical role of assessment and evaluation practices beyond quantitative methodologies. Section 6 introduces the remaining papers of this Special issue and the last Section briefly discusses lessons to be learned and summarizes our analysis.

\section{Latin America and the context for technical change and innovation in the 2000's}

Most Latin American countries and regions are effectively realizing the opportunities for investments in the knowledge base, but still facing a long gap in investing in that knowledge base, as quantified by the level of investment in R\&D and its relatively reduced level for many decades in relation to the practice of industrialized countries. Figure I extends the data published by UNESCO (2010; for 2002-2007) for the period 2002-2012 and compares the world shares of GDP and of GERD (Gross expenditure in R\&D) for the G20. It is important to note that the most dynamic economies (including USA, Germany and China) keep increasing their gross expenditure in R\&D and, above all, are characterized by a world share of GERD higher than their world share of GDP. The most notable figure is that of China, that has increased over the decade under analysis its world share of GERD from 5 to $15 \%$, surpassing its world share of GDP. On the other hand, South American levels of R\&D investment remain relatively small (Batelle, 2013), albeit with some noteworthy national initiatives. For example, gross expenditure in R\&D in Brazil has not been able to surpass $1.3 \%$ of GDP, and in Argentina it is kept as low as $0.6 \%$ (Figure 2). Overall, the region lags in R\&D capacity, with Brazil appearing to have under-performing expectations, with 1.6 fewer publications (in the Science Citation Index) by million inhabitants than Chile, and 5.5 than Germany (Figure 3).

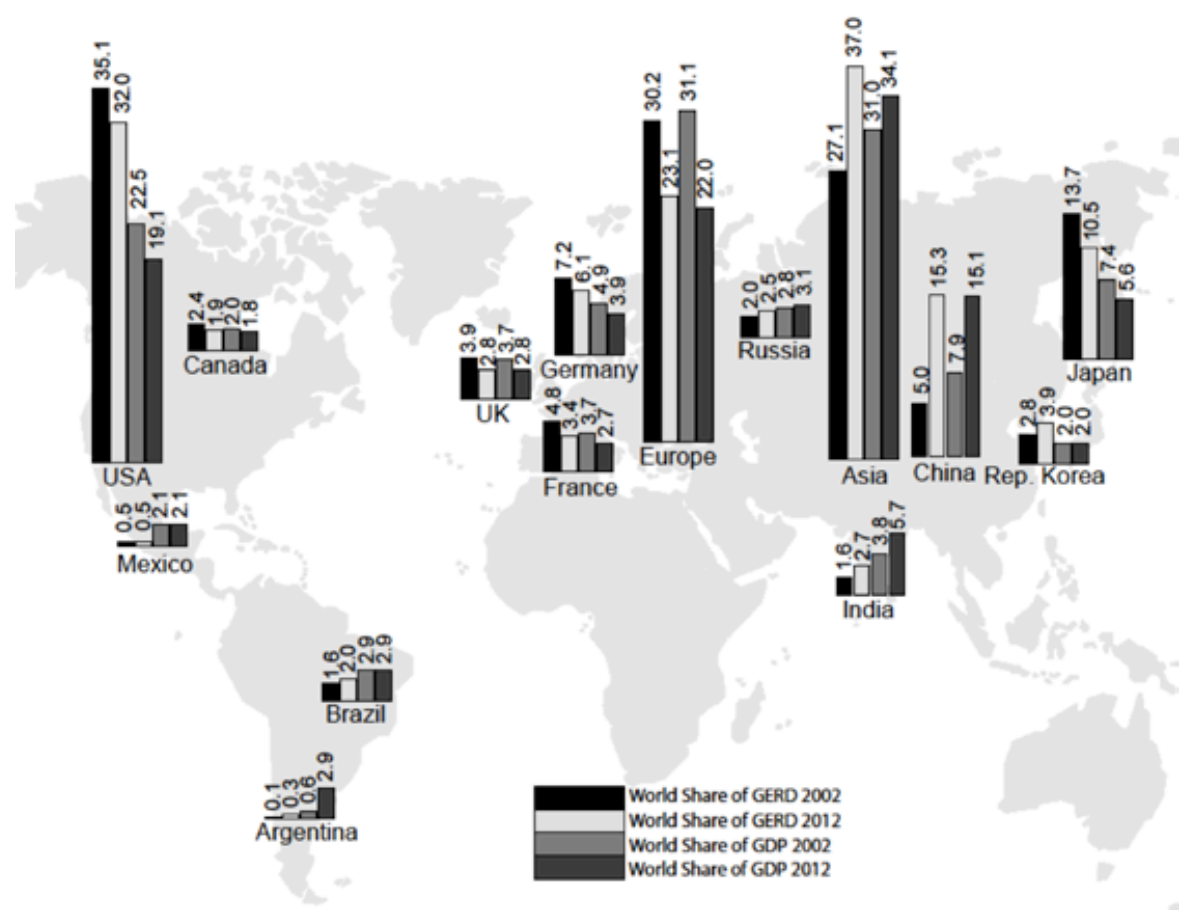

Figure I.World share of GDP and GERD for the G20 over the last decade (2002-20I2); values in \%

ISSN: 07 I8-2724. (http://www.jotmi.org)

Journal of Technology Management \& Innovation (c) Universidad Alberto Hurtado, Facultad de Economía y Negocios. 
Although Brazil, Argentina, Mexico and many other Latin America countries more than doubled their scientific capacity over the last decade, when measured in terms of publications by million inhabitants, the systematic gap over decades in relation to industrialized countries has been attributed to continuous low investment levels in R\&D. This can be quantified in terms of the cumulative gross domestic expenditure on R\&D for the first decade of this century (i.e., 2000-2010), which shows very low relative levels for Latin
America, when compared internationally. For example, the accumulation of investment in R\&D in Brazil over the decade under analysis was half of that in Korea, 3 times smaller than that in Germany and about 3.6 times smaller than that in China. Following Heitor and Horta in this special Issue, these very low levels of investment in R\&D are not contributing to foster adequate advanced training levels for skilled people and are lagging behind modern values to foster the desire to create, explore, and meet emerging challenges.

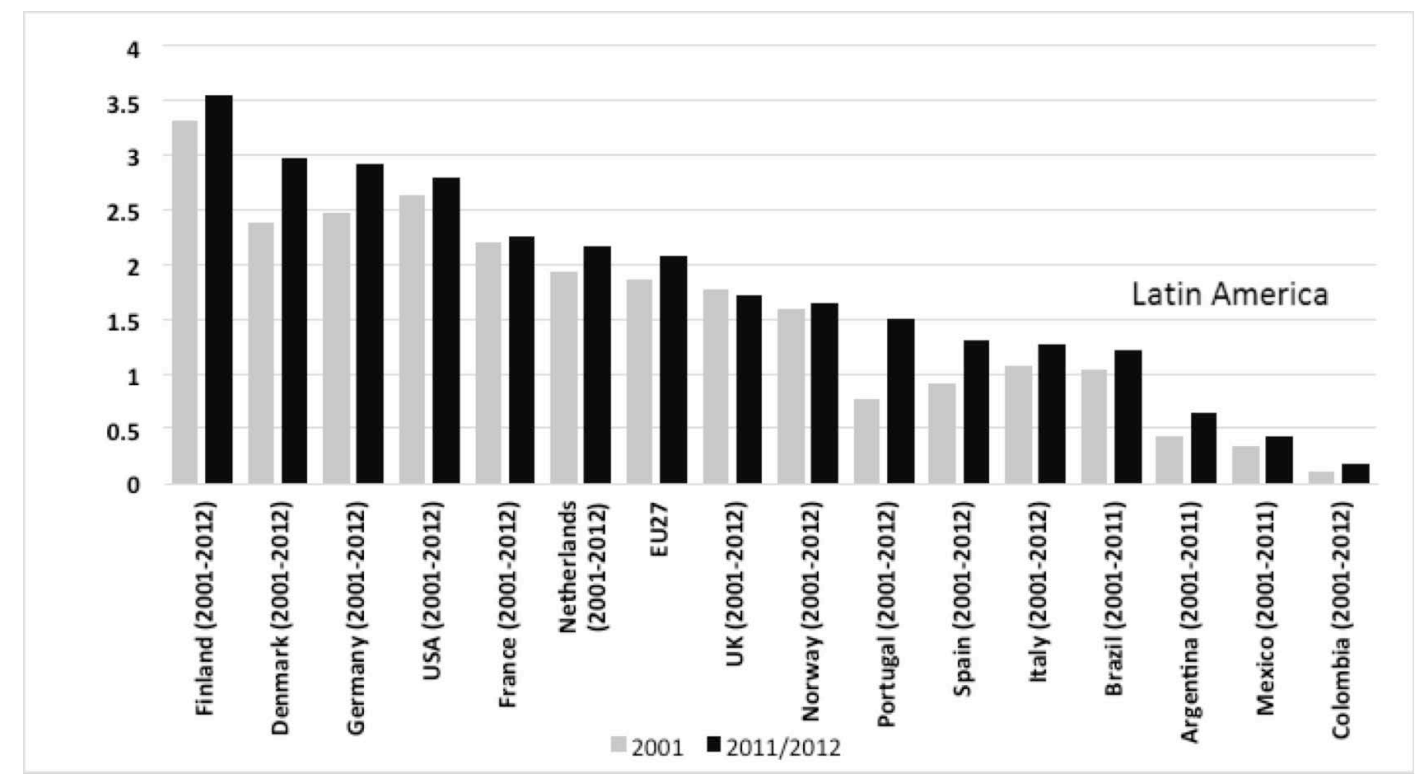

Figure 2. Evolution of GERD / GDP over the last decade (2000-2012) for a sample of selected countries. Source: UNESCO Institute for Statistics, EuroStat.

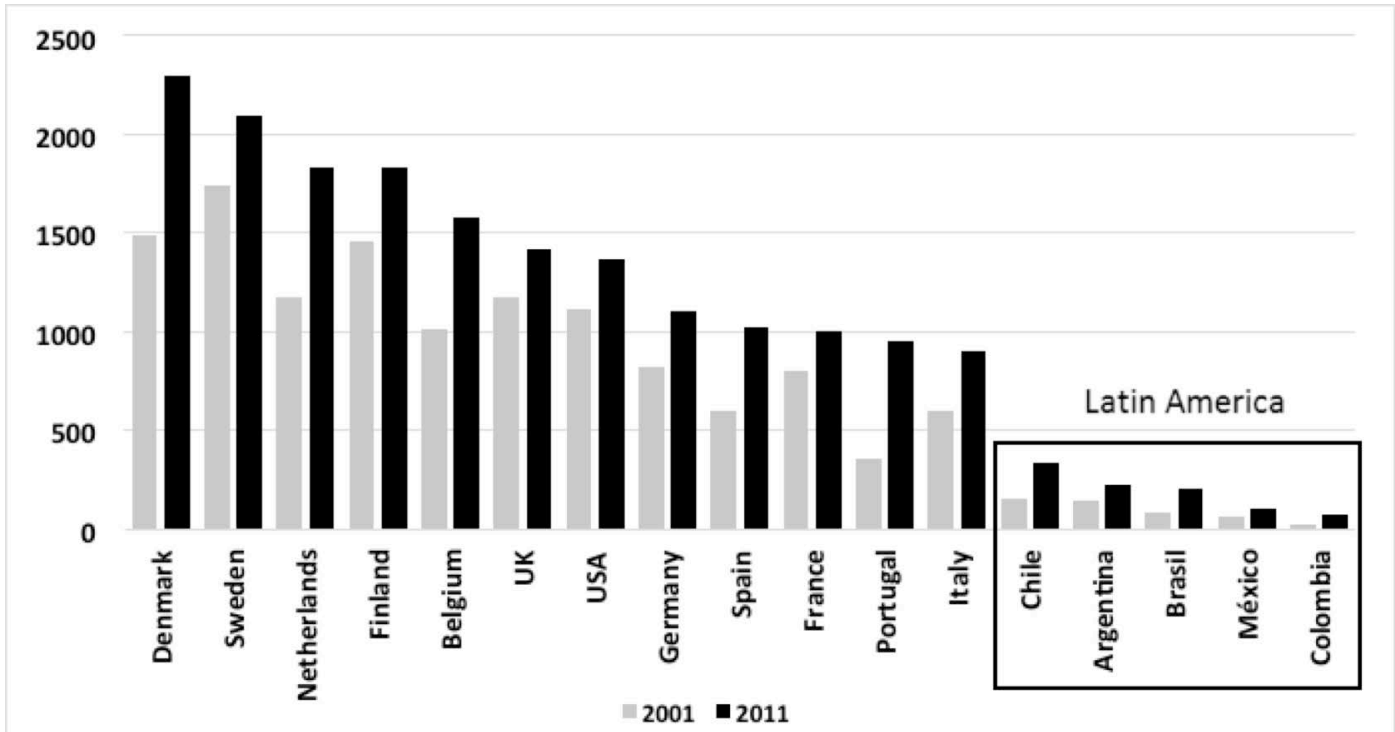

Figure 3. Evolution of number of publications, in the Science Citation Index, by million inhabitants over the last decade (2000-2012) for a sample of selected countries. Source: DGEEC, RICYT 
Although the broad picture taken from international comparative assessments suggest a "lost decade" for technical change in Latin America, analysis has shown that Brazil and most Latin American countries are now facing the need and the opportunity of large investments in science, technology and higher education, aiming at responding to the explosive social demand for higher education and to the vast social and political transformations already induced by new waves of educated youth (see, for example, UNESCO, 2010). These investments not only seek new skills but also the certification of quality that may be expected from working together with well established academic and scientific institutions from developed countries. In addition, new research on the design of higher education at a world level and in very different socio-economic and cultural contexts is expected to help guiding the modernization of Latin America societies.

Regarding National Systems of Innovation, in Latin America, in general, they hold a marginal position in the world. They present a poor integration among C\&T agents and they are not enough connected to productive and social demands. In consequence, although there is some potential, in the most of the countries they present a low innovative dynamic, mainly due to the fact the the role performed by firms is not recognized and awarded. Nevertheless, recent C\&T policies has changed their focus, from C\&T to Innovation. This mean a tentative effort to leverage traditional structures by using new models of promoting cooperation by the agents, industry, academy and government. This situation occurs in challenging times, considering the emergence of China and other emerging economies (Castro and Castro, 20I2), as well as the current international financial situation, with individual people and corporations increasingly believing in science and technology, as well as with unprecedented ways to access knowledge and to diffuse consumer goods worldwide. These are also times of emerging risks, most of them associated with the concentration of people in cities, involving complex technological systems, in some cases, without the proper understanding of how to speedup and improve the processes that enable investments in R\&D and human capital to be transformed into economic growth and productivity gains in a specific region. But these are also times of unprecedented opportunities for science and technology and to modernize higher education and promote new learning systems across disciplines to build human capital and stimulate wealth creation across world regions.

To contribute to our understanding of these and other related issues, while bearing in mind the shaping factors of the emerging globalized economies and the current international situation, next section launches the discussion of the necessary conceptual framework we need to guide future policies.

\section{A conceptual approach: Beyond national systems of innovation}

The concept of "national systems of innovation" has evolved during the last three decades, first in association with the need to fight against "market failures", then against "system failures" (e.g., Lundvall, 1992; Nelson, 1993). And it helped building new nationalistic policies all over the world, but in times in which business and science are becoming increasingly transnational. The end result has been a relative frustration of national policies, on one hand, and a further move toward the multi-nationalization of business, on the other.

This requires many observations and, certainly, deepening the debate in relation to the current economic and social situation in the US and EU, as compared to those in newly industrialized regions and in particular, LatinAmerica andAsia. First, the myth of "national" high tech industries and related policies to protect them requires to be better understood, if analyzed in terms of the increasing unemployment rates. Second, the debate itself on "national innovation policies" is in any case naïve. No country, even in non-democratic regimes, ever seems to have had a broad, well-coordinated innovation policy, mainly because of the complex structures associated with any "innovation ecosystem". National policies do not imply closing boundaries and denying international trade, foreign investment and international cooperation. They rather concentrate in improving spill-over effects of such international interactions.

Looking at the last two decades, the picture that is emerging at a global level is not very much different from that discussed by Ostry and Nelson (1995) in the early 90's. In other words, one of increasing internationalization of private business strategies, while government innovation polices and science funding agencies remain overwhelmingly national. This is leading to new dilemmas for policymaking and to new sources of international friction, although with new boundaries and new players. The key issues to answer include what are the implications of increasing technoglobalism for national and international innovation policies, namely innovation policies in Latin America countries? And, also, what new approaches are required to reduce international frictions and where do public policies need wider integration?

For the case of the US, the key message that emerges from analysis of long-term patterns of investments in S\&T is that of a diversity of policies that led over time to increased opportunities for citizens, as well as to increased institutional specialization based on a clear separation of the role of private and public incentives to support S\&T (Conceição et al. 2004). 
For Europe, recent analysis (Aghion et al, 20l I) also argues that the debate on climate change, the recent financial crisis, and the new Chinese dominance of the world market, mean that there is a need to revisit the role and design of industrial policy. This has been used to justify the need for renewed targeted sector-based intervention of governments, namely to redirect production and innovation towards clean technologies, as well as to make industrial policy more competition-friendly and more innovation-enhancing.

Analysis in the literature has also clearly shown that China's capacity to innovate is evolving, but still limited as compared especially to the capacity of the US (see, for example, McKinsey Global Institute, 20I2).A similar comment could be raised about Brazil and Latin America, suggesting that there is a large scope to better develop innovation policies in a broad international context, well beyond national borders. In addition, a new paradigm of international academic, scientific and technological cooperation that seems to emerge, as discussed below.

\section{Strengthening the pillars}

At a time of increasing financial difficulties due to public budget constraints, there is the expectation that links between research activity and its application in society will be reflected in more direct and immediate financial $\mathrm{fl}$ ws. However, this perception is leading to a process of institutional convergence between what universities do (and are supposed to do) and what firms and other agents do (Heitor, 2008). In fact, almost two decades after Burton Clark launched the idea of "entrepreneurial universities" (Clark, 1998), there is still much to learn about their impact and analysis has clearly considered this convergence a potential threat to the institutional integrity of the university and the future of scientific research due to the commoditization of knowledge (Nelson, 2004).

The issue is not to "save the university", but rather to understand who will play the fundamental and unique role that universities have played in the overall cumulative system of knowledge generation and diffusion. It is clear that many elites worldwide (including in the US and EU) are not willing to allow this integrity to be jeopardized. By misunderstanding national policies towards university-based research, there is a grave danger that university policy in Latin America (and elsewhere) will destroy these basic functions, which would be detrimental to the global production of knowledge, but would also certainly harm the development prospects of many regions in Latin America.

Overall, changing the patterns of teaching and learning, strengthening the role of research and university-science relationships, making students' work more active, and fostering student-centered education schemes, are the ultimate goals of many leading institutions, which should be better understood at an overall level. Following such practices, skills, attitudes and values, education at all levels should take into account that learning a new practice requires moving through discovery, invention, and production not once, but many times, in different contexts and different combinations. To achieve these objectives, we must learn from new research and, certainly, we also need to foster evidence-based project and experimental work, as well as to focus our attention on the transferable skills students should acquire. But we also need to reduce drop-out rates in tertiary education and to involve students in research activities from the early stages. In summary, we need to go beyond the structure of tertiary education and gradually concentrate our efforts on measuring and taking stock of the diversity and evolution of specific student-cente ed parameters.

But, in addition to that argument, we argue for a deep discussion about the complexity of stakeholder engagement and the politics of trust building in science and technology worldwide. This is because, beyond any single measure, one may argue that it is the public understanding of science and the related level up to which people trust in academic and scientific institutions that determines the success of science and innovation policies. It is under this context that the systematic development and promotion of activities to foster science awareness, science education and the role of science in the daily life of citizens has been implemented in many regions and countries with a high level of priority in the innovation policy agenda.

\section{Innovation and socio-economic resilience}

It is clear that technoglobalism and the globalization of trade and supply chains led to the emergence of increasingly competitive global markets and to facilitated access to new suppliers, independently of their geographic location (Berger, 2013; Mazzucato, 2013; Locke and Wellhausen, 2014). This has allowed countries and regions with strong technological and industrial bases to profit on the lowering of trade barriers to access new markets, while the majority of firms located in other regions remained confined to local markets. In addition, the analysis of the overall trend on moving towards knowledge intensive services and its relation with job creation and economic growth requires some pragmatism. This is because, in parallel to technoglobalism came post-industrialism, promoting services as the new developed countries' economic growth overtook manufacturing industries. Captivated by the prospects of accelerated and cost-effective economic growth, many countries, the United States included, started shifting their focus from manufacturing industries to knowledge-intensive services (Hepburn, 20I I; Ghani and Kharas, 20I0). 
The result is emerging with many regions worldwide lagging behind, including Latin America. In fact, evidence shows that, when compared to knowledge-intensive services, hard industries have higher labor productivities, a more balanced income distribution, higher income growth rates and the ability to generate exports, which are negligible in the case of services (Nairn, 2002; Fingleton, 1999).

Looking at the US and other most developed economies (including Germany) for comparative purposes, we can identify some common factors, but also opportunities that need to be understood in international comparative terms: strong industrial bases, diversified economy, and supply chain and knowledge networks' complexity (Amsden, 200I; Hidalgo and Hausmann, 2009).

Approaching this question for Latin America requires the setting-up of a large task force for the "observation" of industrialization, to cover various aspects, including:

- The geography and dynamics of economic development and specialization - how scientifi, technological and industrial bases evolve and impact socioeconomic development?

- The structure, geography and dynamics of supply chains and knowledge networks in different sectors and markets.

- Policy tools to foster local industrialization processes (e.g., public procurement, local production agreements, public expenditure in R\&D and training). - Deindustrialization processes, characterizing them and identifying, analyzing and governing related risks.

It should be clear that a new generation of industries will drive the economic recovery over the next decade, fuelled by long-term changes in technology, society and geopolitics. The international recession has not been only a point of change, and many argue that it has acted as a catalyst for growth. As the business landscape alters, we will see the emergence of new ways of doing business in an increasingly interconnected world.

\section{Analysis: Stimulating research and economic development and university-industry relationships}

- The Universities/Research Institutes are strongly linked to cultural traditions, where the role of the firms in the innovation process is still not very well recognized. As a consequence,

- The emphasis relies upon knowledge production (papers) and not in their use (patents)

- The investments in R\&D via U/RI's are too little focused on commercial and economic results

- Only the big firms achieve benefits from the interaction with U/RI's. The most of SMF's are excluded of this process due to lack of qualified people to intermediate communications, sophisticated technical problems to call for attention, time to spend with the interaction process, so on.

Our analysis focus on two main topics, as follows: i) managing R\&D at a global scale, together with international $\mathrm{fl}$ ws of human capital, the increasing internationalization of knowledge institutions and industry-science relationships towards productivity gains and new markets (as described in this section); and ii) the social construction of technological systems, involving the public understanding of science and technology (see next section).

In this section we further extend the issue of reinforcing innovation in Latin America. This has become a "commonplace" worldwide, with the US system often taken as a world reference, although analysis has shown that it is of utmost importance to understand its policy diversity and mix set of public and private incentives (Conceição et al., 2004). Moreover, its long history of past investments and current division of labor or specialization cannot be replicated in systems with a lower scale and complexity (Mazzocato, 2013). The key elements of the US academic history are those of diversity of policies and increasing "institutional specialization" and of the clarification of the unique roles of the private and public incentives to support science and technology (Conceição et al., 2006).

The same way the US system as a whole is taken as a worldwide reference, the US university system is also used as a role model for its fast rate of response to the economic changes and contribution to the creation of wealth through relationships with firms (NAE, 2003). The understanding, that the universities are gradually viewed as important engines of economic growth and development instead of mere institutions of higher education learning is evident for many years (see, for example, Saxenian, 1986). There is increasing evidence of their importance as developers of regional industrial and technological development (Cooke and Huggins, 1996). This is a role that US universities, especially research universities, have assumed throughout the second half of the 20th century (Rosenberg, 2002).

ISSN: 07I 8-2724. (http://www.jotmi.org) 
Here, too, as with the whole US system, there is the perception that private funding associated to a high level of industry-science relationships is very high and stimulates a very dynamic academia, which contributes in a much more direct way and with bigger impact to the socioeconomic development at both regional and national level. The possibility of getting funding from private sources and private incentives (e.g, Intellectual Property Rights) is very appealing for universities that strive with increasing demands for change and for being more closely engaged with society. However, research suggests this to be potentially dangerous for the development of universities (Conceição et al, 2006). At a time that universities have increasing financial difficulties derived from public budget constrains, there is the expectation that these closer links between research and application and usefulness in society will be translated in more direct and immediate financial fl ws (Neave, 1995). This perception is leading to an institutional convergence between what universities do (and are supposed to do) and what firms and other agents do.Above all, we follow Charles Vest (2007), former MIT's President, which stated: “... what is best about American higher education - we create opportunity. That is our mission. That is our business. That is first and oremost what society expects of us."

To address this issue, international academic and scientific cooperation may help creating, monitoring or coaching and steering research programs with industry in developing countries, their early inclusion in international networks, and the affiliation of private companies to academic and research programs (Heitor, 20I4).

\section{Promoting Internationalization}

Following our observations in previous sections on the role of international networks on the production and dissemination of knowledge, we now deepen the issue of reinforcing higher education systems by focusing on the increasingly relevant theme of internationalizing higher education and industry-science relationships.

Our main hypothesis is that a new paradigm of international academic and scientific cooperation seems to emerge as a major shaping factor for development at an unprecedented level. It is well known that universities from developed countries are now operating internationally, addressing not only potential students individually (this was the traditional paradigm), but increasingly addressing foreign universities and firms local authorities and governments, in order to develop new types of institutional arrangements (Knight, 20II).
These include helping creating, monitoring or evaluating emerging institutions in other countries, transferring organizational skills, commercializing technology, operating training programs for teachers and researchers, contributing to higher education and research capacity abroad and to the marketing of its benefits for economic and social progress in other societies (Altbach and Knight, 2007). Such new arrangements may also include the coaching and steering of research programs in developing countries, their early inclusion in international networks, and the affiliation of private companies to academic and research programs (Heitor and Bravo, 20I0).

However, this new paradigm in international academic cooperation does not appear to match the usual model for exporting services. Franchising, for instance, may seem attractive at short notice but its glamour fades away under increasing academic and political criticism (Kim and Zhu, 2010). It seems that a new reality is emerging, in which the export of services is intimately associated with the development of national institutional capacities deriving their strengths from the much needed accumulation of qualified human resources, as well as from institutional participation in and recognition from international academic and research networks.

Although it is well known that this process will depend on the level of foreign faculty and student involved, analysis has also shown that it is critical that the internationalization process is molded to the characteristics and institutional missions of the university in order to preserve its own institutional integrity. In this context, Horta (2009) argued for the need of research-oriented universities to start focusing the internationalization of the student body on postgraduate students. He also argued that, in researchoriented universities, the internationalization of the faculty is strongly related to the internationalization of postgraduate students and thus, in alignment with the scope of research activities.

It is under this context that our focus is to broaden the ultimate goal of internationalizing the university in emerging economies in terms of university networks able to foster attractive and competitive research and learning environments and to attract and train highly qualified human resources (Horta, 2010). The key issue is the creation of international partnerships able to strengthen institutions and the necessary critical masses to compete at an international level and, at the same time, guarantee the adequate level of institutional integrity of universities in emerging and developing regions (Marginson, 2004). These networks may have an important impact in doctoral education, helping to attract students, as well as to help training their future teaching staff in times when higher education systems at those regions are becoming increasingly relevant. 
Understanding the new paradigm of international partnerships in higher education will gain from our increasing knowledge of the operational advantages and shortcomings of large international research consortia and organizations. It also requires the understanding of the local characteristics of the processes of technical change and of their specific regulatory and institutional constraints and it calls upon our knowledge of the social construction of technological systems. This new model of academic cooperation, that includes but does not seem to be a hostage of the traditional forms of services' international commerce, may derive its uniqueness from the very nature of academic communities and from the strong meritocratic and universalistic ideals that prevail in science on an international scale, as well as by the $\mathrm{fl} \mathrm{w}$ of students and researchers, and by the citizen sense of being part of a "mission" for scientific and social development that motivates some of the best professionals in academic institutions worldwide. However, under which conditions is such a model sustainable?
To answer this question, Table I summarizes major lessons learned from the Portuguese experience in setting-up international research networks (Heitor and Bravo, 20l0). It considers three main focuses, including: i) training the trainees, through co-hiring of young researchers and exchange programs for faculty; ii) institutional building, by promoting the role of scientific institutions in society, their links with the private sector and adopting policies that foster the creation of critical mass, including those oriented towards fostering R\&D consortia; and iii) test beds and thematic R\&D networks, facilitating the integration of researchers and scientific institutions in international thematic networks with local relevance, as living laboratories for the production and dissemination of knowledge and facilitating ideas for markets worldwide. Test beds should be assembled and integrated in international collaborative programs in a way to boost local companies' capacity to export and access emerging markets.

\begin{tabular}{|l|l|}
\hline Major objectives and policy instruments & Justification \\
\hline $\begin{array}{l}\text { People } \\
\text { Train, attract and co-hire researchers, fostering } \\
\text { their exchange and the training of a teaching } \\
\text { body }\end{array}$ & $\begin{array}{l}\text { Sustain excellence and internationalization in doctoral pro- } \\
\text { grammes } \\
\text { Foster and systematize the hiring of researchers with PhDs }\end{array}$ \\
\hline $\begin{array}{l}\text { Institutions } \\
\text { Reinforce and promote the role of scientific insti- } \\
\text { tutions in society, and their links with the private } \\
\text { sector (promoting R\&D in business enterprises) }\end{array}$ & $\begin{array}{l}\text { Reinforce institutional evaluation mechanisms, in order to } \\
\text { improve systemic and organizational efficiencies } \\
\text { Adopt policies that foster the creation of critical mass, } \\
\text { including policies oriented towards fostering R\&D consortia. } \\
\text { Promote the training of a new generation of technicians and } \\
\text { other human resources to support R\&D activities }\end{array}$ \\
\hline $\begin{array}{l}\text { Test beds and thematic R\&D networks } \\
\text { Facilitate the integration of researchers and } \\
\text { scientific institutions in international networks } \\
\text { focused on "test beds", as living laboratories for } \\
\text { the production and dissemination of knowledge } \\
\text { with local relevance and facilitating ideas for } \\
\text { markets worldwide }\end{array}$ & $\begin{array}{l}\text { Reinforce international partnerships and foster participation } \\
\text { in international knowledge-based networks as a way to im- } \\
\text { prove scientific quality and the employability of researchers } \\
\text { Foster S\&T thematic networks in terms of test beds and liv- } \\
\text { ing laboratories that can boost companies' capacity to export } \\
\text { and access emerging markets. }\end{array}$ \\
\hline
\end{tabular}

Table I - Potential guidelines to foster international research networks

ISSN: 07 I8-2724. (http://www.jotmi.org) 
The discussion above leads to the idea that a new paradigm of technology commercialization through international academic and scientific cooperation is also emerging at an unprecedented level.We refer to the capacity to turn sciencebased inventions into commercially viable innovations and related new potential factors of progress on a global scale, in association with a growing perceived evidence of the potential benefits resulting from economic appropriation of the results and methods of science by society. Our approach is on sustained growth in emerging and developing regions, which can occur only with the continuous introduction of truly new goods and services, namely in the form of radical technological innovations that disrupt markets and create new industries.

At this stage it should remembered that the accumulation of knowledge by skilled people and institutions in the area of technology-based entrepreneurship require a specific learning process, that takes place together with the building-up of the necessary critical masses in the research community, but needs to be oriented to external and emerging markets worldwide. Making-off local knowledge intensive communities, which are associated with local and specific institutional and university contexts, able to operate in global and sophisticated markets requires organized networks fostering new competences in international technology commercialization and diffusion. In other words, we propose a consideration of the challenges associated with implementing country- and regional-wide "university technology enterprise networks" for stimulating competences in a way that fosters access of technologybased start-ups to emerging markets worldwide.

\section{Engaging new technology based firm}

Technology-based entrepreneurship is increasingly seen as a key element of regional competitiveness and that has been taken as "the model" for many other regions and countries worldwide. Silicon Valley and Route 128 in the BostonCambridge area, the most dynamic regions in the world today in terms of growth and innovation, were propelled mainly by new technology and the creation of startups - Apple, HP, Google, and Intel, to name a few. At the same time, start-up companies are also becoming global enterprises and engage in services, manufacturing, and research throughout the world, with strong links to universities and research groups. Others are going beyond their borders to procure products and services at lower prices, often from new companies or subsidiaries in countries like China, India and Brazil. Welltrained engineers and computer scientists from Bangalore and Shanghai are competing for jobs that traditionally went to their counterparts in Europe and the US.
At the same time, universities in Latin America (and worldwide) are attempting to "emulate" their US counter parts and foster a range of technology transfer offices and commercialization activities, together with industrial liaison programs, mostly intended to foster entrepreneurial environments and the launching of technology-based start-ups. The large number of technology parks launched throughout Latin America over the last 15 years is the clear evidence that the concept has become a "common place". Bringing ideas to the market is their main goal.

Notably, beyond the concentration of people and skills in a number of regions, a key issue that has differentiated North America from many other countries and regions is the availability of a mix of public and private funding sources, in a quite diversified pattern and, most of them, of easy access to SME's. It is in this context that a few countries have tried to emulate the SBIR program ("Small Business Innovation Research"), which remains unique in many of its characteristics. Although many difficulties have been found in the public support to continue SBIR (as well as that of the "Technology and Innovation Program", at NIST in North America), its enormous success and impact should be further acknowledge. This is a program of the outmost importance and relevance that has helped American innovative firms to growth. In addition, many other schemes to fund and support new technology-based firms have been used in America in quite original ways, namely through public procurement through the Defense and Energy Departments.

\section{Promoting science and technology culture}

Our second level of analysis is associated with the need to strengthen external societal links as critical steps in fostering the role of science, technology and innovation in society and to meet the needs of global competition and the knowledge economy. This issue has been discussed in US and Europe over the last fi e decades, either in terms of renewing science education, or creating science culture, and here we reinforce this argument with a specific application to Latin America. 
Following Heitor and Horta in this Special issue, the need is to foster the public understanding of science, as well as to better explain to society the role of scientific and technical development, as well as that of industry. The continued implementation of actions fostering "science for all", as well as that of "thinkering" (see, for example, Michalko, 20II) is a practice to follow, where the concept of "Knowledge integrated communities" appears particularly suitable to facilitate the joint enrolment of researchers, universities and basic and secondary schools in specific projects driving society at large. It is clear that this requires new knowledge about social behaviors, as well as new methodological developments to help moving emerging regions worldwide towards a knowledge society in a fast moving landscape. The objective is to integrate systems of knowledge and ways of practicing, where schools interact with universities in systematic ways, building routines of cooperative work.

Figure 4 complements the analysis of the previous section and shows that the gross expenditure on R\&D per capita in any Latin America country is still well below any acceptable value at an international level. In addition, it has not increased over the last decade at the level of the most industrialized countries. For example, after correcting for parity and at constant prices of 2005, the annual per capita expenditure in R\&D in Brazil is about 8 times smaller than that in Germany and one tenth of that in North America. Although it should be noted that it has notably increased about $50 \%$ over the period 2000-201I, the related increase in Germany was about $67 \%$ and about $37 \%$ in North America. These figures clearly show a long gap in the way Brazilian (and, in general, Latin America) society considers the investment in $R \& D$ as matter of priority.

- In Latin America, in general, the instruments of public policy have been proved very ineffective to promote innovation at the productive sector. They not consider the firm as the focal point of the innovation process, and present:

- Low degree of clarity/explicitness

- Low continuity/high oscilation over the time

- Extremely bureaucratic for access and use

- Low pre-engagement of firms in their definition

- Low atractiveness to stimulate and modify firm behaviour regarding

By addressing societal links as a critical step in fostering the role of science, technology and innovation in society and to meet the needs of the knowledge economy, we should strengthen that the process needs to be based on a solid framework to foster "beliefs in science". Some forty five years after John Ziman launched the discussion on Public Knowledge (Ziman, 1968) and thirty five years after his work on Reliable Knowledge (Ziman, 1978), to appreciate the significance of scientific knowledge one must understand the nature of science as a complex whole. In Real Science (Ziman, 2000), we are reminded that "science is social", referring to "the whole network of social and epistemic practices where scientific beliefs actually emerge and are sustained".

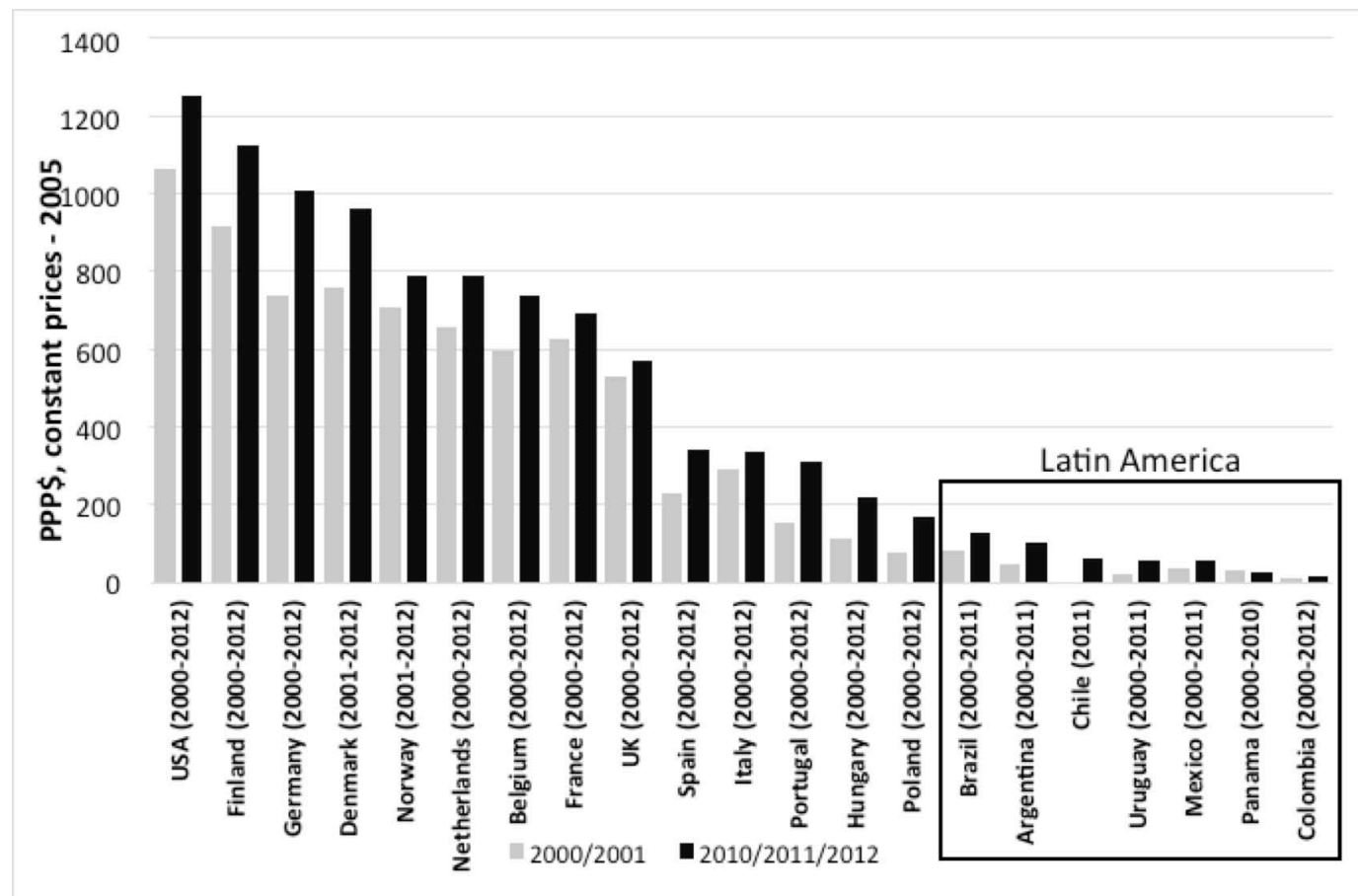

Figure 4. Evolution of GERD per capita (in PPP\$, constant prices - 2005) over the last decade, 2000-20I2; Source: UNESCO Institute for Statistics 
Our goals require the renovation and expansion of the social basis for scientific and technological development in Latin America. This calls upon strong conviction not only from the scientific and technical professions and of public and private research organizations, but also from students and from the general population. The growing appropriation of scientific and technological culture by society is thus one of the central aspects of the argument discussed in this paper. It requires a strong foundation in effective assessment and evaluation practices.

\section{On the role of assessment and evaluation practices beyond quantitative methodologies}

In discussing lessons learned over the last decades in the development of science, technology and innovation capacity, we must certainly refer to assessment practices, at two main distinct, but related levels. First, the research evaluation practice set as an independent system from education and teaching. Second, the implementation of an independent institutional accreditation and assessment of teaching programs and higher education institutions based on the best international practices.

Creating, strengthening and restructuring a network of research centers in Latin America, including those in universities and/or related non-profit institutions, require the implementation of a systematic research assessment practice, with a periodic nature (e.g., every three years) and with direct impact on funding levels. This has been widely established in industrialized countries and we argue that there is no other way to foster research capacities in emerging regions worldwide. Also, it should be entirely implemented making use of external experts and/or with internationally relevant and independent institutions.

In addition, independent accreditation and assessment of teaching programs already in place in Latin America and higher education institutions do require flexible and stable organizations to be established for an indeterminate period of time. They should be responsible for the assessment and accreditation of universities and their study cycles, as well as the execution of every task intrinsic to the integration of every region in international systems of quality assurance of higher education.
In this process, it is rather important to note that he assessment of knowledge production results should not be based solely on quantitative methodologies. This is because although quantitative evaluative methods may complement peer-review practices, overcoming the recognized criticisms and pointing out the faults of 'pure' peer-review assessments (Relman, 1990), the "extreme" quantification of the academic activity may impose a culture of "bureaucratization of knowledge", which is to be avoided. In addition, whereas research evaluation is a well-consolidated assessment, it is still difficult to measure and evaluate teaching performance (Dixit, 1998).

Also, although certain authors defend the robustness of teaching evaluation processes such as student ratings (Marsh, 2007), faculty and higher education administrators have expressed doubts about their meaningfulness and suitability (Gilliot, 200I). The same problem arises when evaluating faculty work as a whole, or universities as a whole, where institutional evaluation assessments are often revealed to be a paradox as they either rely too much on subjective features or on an excess of quantitative features (Schloegl et al., 2003). In other words, the robustness of performance indicators for research, if complemented by more qualitative procedures provides a sound basis for making judgments.

\section{Introducing this Special issue}

Following this introductory paper, this special issue considers nine papers addressing critical challenges and opportunities for innovation and knowledge-based change in Latin America. Sztulwark and Juncal argue that a new logic in the capitalist accumulation process has emerged in the last four decades at a global level, with major implications for Latin America. Their hypothesis relies in the increasing segmentation of product innovation and product manufacturing activities, and the integration of two alternative types of innovation activities: informational and aesthetic-expressive. Making use of secondary sources of information, three productive chains have been studied: pharmaceutical, apparel and consumer electronics. The results show specificities in the content of innovation, the constitution of entry barriers and the geographical dispersion in each chain.

Reichert and Zawisllak report a detailed analysis of the relationship between technological capacity and firm performance in Brazil, making use of a sample of 133 firms across a wide range of economic activities and firm dimension. Their results reflect a traditional economic structure, which is not yet focused on technological development, but on operational capability, with industries, of fundamentally lower technology intensity, which do not require investments in technological capability to achieve superior economic performance. These industries in relatively stable

ISSN: 07 I8-2724. (http://www.jotmi.org) 
markets, focused on providing products of good quality and on seeking the lowest possible cost. Furthermore, the operational focus is confirmed for medium-low-technology firms such as Petrobras, Vale and Ambev. In general, the paper confirms a historical tradition of a country and a economy concentrated on basic industries.

Guzmán and Brown identify factors affecting innovation efforts of Mexican manufacturing firms and how they impact labor productivity for the period 2004-2006, making use of 2078 establishments. Their results follow the literature and show that innovation propensity depends mainly on firm size. The effect of exports for current markets (mainly in Latin America) is found to be of minor relevance. The access to credit, technological transfer, foreign direct investment and new knowledge appropriability have a positive impact on firm s innovation. Moreover, innovation in shown to be particularly dependent on the full value chain process and, above all, to human capital.

Fabiani and Sbragia discuss the use of fiscal incentives in Brazil and show the importance of public policies to promote investment in R\&D in Brazilian private firms Also highlight difficulties and improvement suggestions for the use of tax incentives provided for by the Good Law - Lei do Bem, which results in a number far below the expectations of the Federal Government of Brazil.

Heitor and Horta focus their paper on the conditions to build reliable science, technology and higher education systems in Latin America, based on international comparative studies, field ork and interviews conducted over the last three years. The analysis shows that science can have a major role in furthering the democratization of society through public policies that foster opportunities to access knowledge and the advanced training of human resources. The authors argue for the need to better integrate science and education policies in a way to further democratizing and promoting socio-economic development through two complementary goals: i) opening access to the knowledge base through higher education; and ii) promoting advanced qualification of skilled people and strengthening research institutions through adequate consideration of human resources and institutional issues in the process of technical change. Their analysis suggest that the need to guarantee higher education diversity, strengthening scientific institutions and investing in a strong science base, is deemed as critical, but goes far beyond policies centered on innovation and industryscience relationships. It requires adequate training and attraction of skilled people, as well as promoting scientific and technological culture among society.
Lepratte presents a theoretical - analytical framework, based on certain contributions of social studies of technology (EST) and neo-Schumpeterian evolutionary economics oriented complex systems (EEC), that allows studying and addressing issues related to innovation processes, technological change and development from Latin American specificit .

The conclusions raised and discussed the scope of the research proposal and suggests ideas for an articulatory ST\&I policy, capable of being oriented to transition processes in multidimensional sense development ..

Solleiro, Gaona and Castañón discuss the results of a new program to promote collaborative networks among firms for improving competitiveness trough innovations. The paper presents State of Mexico's innovation capacities the institutional framework and the main actors. The results show that SMEs had lack of experience in innovation but they increased their investment in innovation projects. Based on that analysis the authors conclude that success of innovation policies is highly dependent on previous experience and learning abilities of firms

Flores, Rincón, Baralt and Rincón present an analysis of the relationship between the Law on Science, Technology and Innovation and the Hydrocarbons Law in Venezuela. They present a conceptual framework that allows to place the context of public policy analysis. Then using the interpretive method and theoretical background on public policy analysis, analyze the relationship between the afore mentioned laws.Arises as a result making it possible for both legal instruments Venezuelan political process is part of the country but designed to generate public value and meet the needs of stakeholders.

Sztulwark and Juncal set a new logic in the capitalist accumulation process that has emerged in the last four decades. Their hypothesis stands that this new logic expresses itself in the manufacturing industry through the increasing segmentation of product innovation and product manufacturing activities, integrating two alternative types of innovation activities: informational and aesthetic-expressive, and a methodology based on the analysis of secondary sources of information. They studied three productive chains: pharmaceutical, apparel and consumer electronics. The outcome of this research confirms the formulated hypothesis allows the detection of specificities in the content of innovation, the constitution of entry barriers and the geographical dispersion in each chain. 
Finally, Gonzalez and Jimenez present an interesting analysis of the main instruments for the occupational insertion of highly trained human resources in Chile. They show that the programs for industrial sector insertion have poor outcomes. On the other hand, the post doctoral positioning scholarships have been very successful due to the fact that they represent a solid bridge between the $\mathrm{PhDs}$ formation and their final insertion in the academic world. The authors propose that it will be difficult to sustain this policy over time, due mainly to the fact that the scale of local universities imposes a restriction in the number of researchers they can support. There exists as well an unbalance between the production and results of the academic research output, which contributes to the consolidation of the local academic system but in many cases overlooks the eventual technology transfer to society. The authors think that it is imperative that the government designs new instruments and incentives for the private sector to take advantage of these highly trained human resources. On the other hand, universities should have an active role in the generation of intellectual property policies that allow administrating in a better way the assets arising from the appropriability of the scientific $\mathrm{kn}$ wledge.

\section{Discussion and summary}

The rapid development of science and technology at a world level, particularly in many "transition economies" and developing regions across the world, as well as the growth in higher education worldwide and the prospects for its rapid evolution in many developing countries in the years to come, is calling for the need to better understand and frame inclusive science, technology and innovation policy actions in Latin America.

But developing knowledge-based practices in Latin America requires the need to concentrate public policies and institutional strategies on a myriad of issues that will ultimately open the "Black Box" associated with all type of institutions, preserving autonomy while building-up a new set of relationships with society at large and introducing an "intelligent accountability" associated with a renewed structure of incentives.

Two main emerging issues drive the rationale for this paper and Special Issue. First, the recent explosion in demand for higher education by millions of young people around the world (Altbach et al., 2009) related to the growing perceived evidence of the potential benefits resulting from economic appropriation of the results and methods of science by society (see, for example, in this Special issue, the paper by Heitor and Horta). This is associated with the changing perception of the "academic/scientific divide" at world level. Many developing regions and countries, including in Latin America, are now facing the need and the opportunity of large investments in science, technology and higher education (public and private), aiming at responding to the explosive social demand for higher education and to the vast social and political transformations already induced by new waves of educated youth (Roberts and Hite, 2007).

This is the case of the recent investments in hundred new campuses in Northern Brazil, Ecuador, or Colombia (among many others in China, Russia and other developments in South Africa, Rwanda, Turkey). These investments not only seek to foster new skills and knowledge, but also the certification of quality that may be expected from working along with well-established academic and scientific institutions from developed countries. Such institutional arrangements provide new forms of expansion, as they tend to help securing new financial or human resources, and to challenge their own traditional competences and agendas. The question that arises is how far those investments are enough to foster and spur economic development in the short term. 
Figure 5 quantifies the evolution of the cumulative gross domestic expenditure on R\&D for the first decade of this century (i.e., 2000-2010) for a sample of selected countries and show very low relative levels for Latin America, when compared internationally. The figu e considers a logarithmic scale to facilitate potential comparisons and shows, for example, that the accumulation of investment in R\&D in Brazil over the decade under analysis is similar to that of The Netherlands and Italy, 3 times smaller than that in Germany and about 20 times smaller than that in USA. We argue that these relatively low levels of investment in R\&D are not contributing to foster adequate advanced training levels of skilled people and are lagging behind modern values to foster the desire to create, explore, and meet emerging challenges.

Second, the relative low level of sophistication of firms in Latin America and the related low income per capita that still characterizes the region, which has been, for many years, associated with very low technology intensities and R\&D investments (see, for example, the papers in this special issue by Sztulwark and Juncal, by Reichert and Zawisllak and by Guzmán and Brown). Figure 6 compares the share of gross expenditure in R\&D, GERD, by sector of performance for a sample of selected countries in $201 \mathrm{I}$ and identifies the critical low level of business R\&D that characterizes most Latin American countries and regions.

This is important because "technoglobalism" and the globalization of trade and supply chains led to the emergence of increasingly competitive global markets and to facilitated access to new suppliers, independently of their geographic location (Ostry and Nelson, 1995; Berger, 2005; Mazzucato, 2013). This has allowed countries and regions with strong technological and industrial bases to profit on the lowering of trade barriers to access new markets, while the majority of firms located in other regions remained confined to local mar ets. 

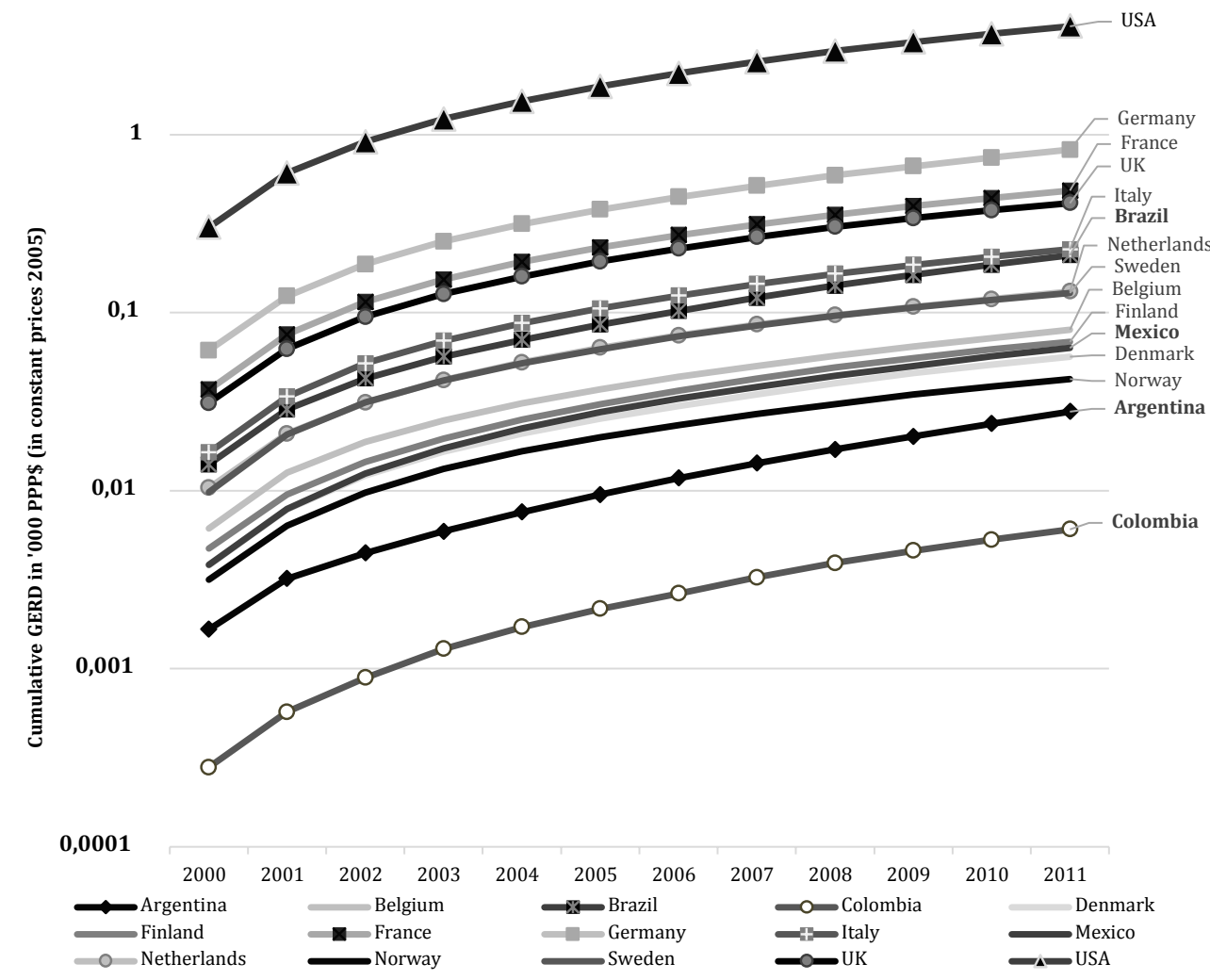

Figure 5. Cumulative GERD over the last decade, in logarithmic scale (base 10) and in '000 PPP\$ (in constant prices - 2005). Source: UNESCO Institute for Statistics

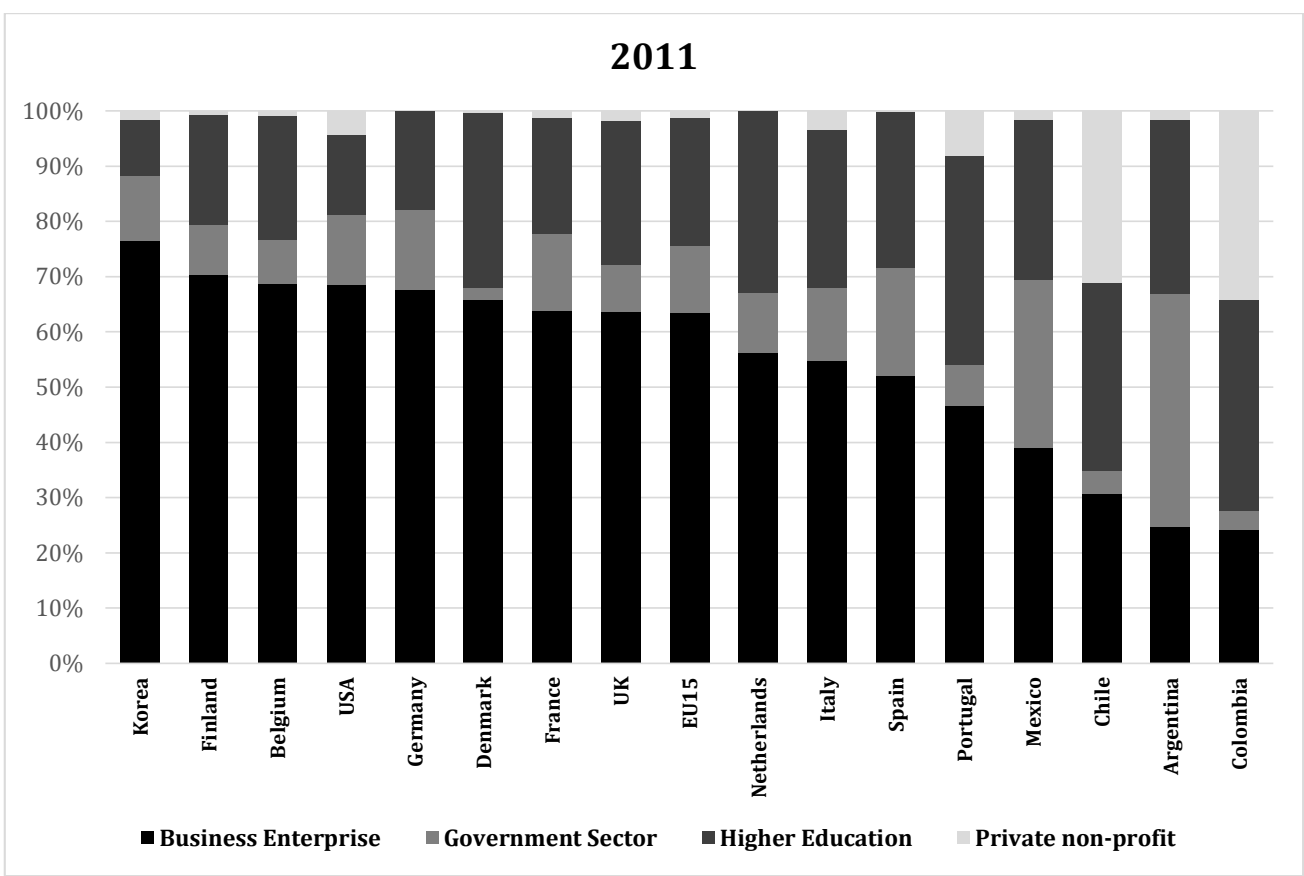

Figure 6. GERD by sector of performance in $201 \mathrm{I}$; Source: RICYT, OECD. 
The analysis and discussion of the two effects described above are discussed in this paper (and, in general, in the Special Issue) with the ultimate goal to foster a broader research framework to approach industrial innovation and technology management in Latin America. It is our understanding that research should look at how industry in distributed, and how production is done across countries and regions, and how capabilities are being used in different countries and regions. In fact, this framework is leading to several research programs in centers and universities around the world, including the "Production in the Innovation Economy" project at the MIT (Berger, 20I3; Locke and Wellhausen, 20I4), and leading to a significant body of research in Brazil on industrialization, namely through regulation and local content policies (Apolinário e Silva, 20I I; Cassiolato et al., 2008; Salles-Filho et al., 20I0).

We should note that by attempting to bring together the analysis of the supply side of technical change (through the identification of human capacity and skills) and of the demand side (through the analysis of firm competencies and knowledge intensity), we aim to promote a dialogue oriented towards industry-science relationships and the building-up of a modern labor force in Latin America. This requires strengthening experimentation in social networks, which necessarily involves $\mathrm{fl}$ ws of people. It is the organized cooperation among networks of knowledge workers, together with different arrays of users that will help diffuse innovation and the design of products and services (Ernst and Kim, 2002). But establishing these innovation communities requires the systematic development of routines of collaboration on the basis of formal education programs, sophisticated research projects, and a diversified and non-structured array of informal processes of networking (see, for example, Saxenian, 2006; Tung, 2008).We argue this requires a new paradigm of public policies to foster international cooperation in science, technology and the economy, bringing together scientific institutions and firms orldwide.

To cope with such a variety of demands and with a continuously changing environment, we all know that higher education systems, in particular, need to be diversified But the challenge of establishing modern higher education systems requires effective international networks and a platform of research institutions, notably for stimulating the political debate among the various stakeholders and for assisting in the networking of national constituencies promoting the positioning of our institutions in the emerging paths of brain circulation worldwide.

\section{References}

AGHION, P., Julian Boulanger, J. and Cohen, E. (20II), “Rethinking Industrial Policy”, Bruegel Policy Brief, June 20I I

ALTBACH,P.G., and Knight,J.(2007), The Internationalization of Higher education: Motivations and Realities. Journal of Studies in International Education, I I, 3-4, pp. 290-305.

ALTBACH, P., Reisberg, L. and Rumbley, L.E. (2009), "Trends in Global Higher Education:Tracking an Academic Revolution", Paris: UNESCO

AMSDEN,A. H. (200I), "The Rise of "the Rest" - Challenges to the West from Late-Industrializing economies", Oxford University Press.

APOLINÁRIO, V. and Silva, M.L. (ed.) (20I I", "Impacto dos grandes projectos federais sobre os Estados do Nordeste", EDUFRN, Natal.

BERGER, S. (20I3), "Production in the Innovation Economy", MIT Press, 2013

BIJKER, W. E., Hughes, T. P. and Pinch, T. (1987), “The social construction of technological systems", Cambridge: MIT Press.

CASSIOLATO, J.E., Matos, M.P. and Lastres, H.M.M. (ed.) (2008), "Arranjos Produtivos Locais - Uma alternativa para o desenvolvimento", vol. 2 - Experiências de Política, E-papers, Rio de Janeiro.

CASTRO, C and Castro, L.B. (20/2), "Do pensamento renegado ao desafio sinocêntrico - Reflexões de António Barros de Castro sobre o Brasil”, Campus.

CLARK, B. R. (1998), "Creating Entrepreneurial University: Organizational Pathways of Transformation", Oxford: Pergamon Press.

COOKE, P. and Huggins, R. (1996), University-Industry Relations in Wales. Working Paper. Center for Advanced Studies in the Social Sciences, UWCC.

CONCEIÇÃO, P., and Heitor, M.V. (2002), Knowledge Interaction Towards Inclusive Learning - Promoting Systems of Innovation and Competence Building, Technological Forecasting and Social Change. 69, 7, pp. 64I-65I.

CONCEIÇÃO, P., Heitor, M.V., Sirilli, G. and Wilson, R. (2004), The Swing of the Pendulum from public to market support for science and technology: is the US leading the way? Technological Forescasting andSocial Change,7I,5,pp.553-578

ISSN: 07 I8-2724. (http://www.jotmi.org) 
CONCEIÇÃO, P., Heitor, M.V. and Horta, H. (2006), R\&D funding in US universities: from public to private support or public policies strengthening diversification? in Enders, Jurgen, and Jongbloed, Ben, Public-Private Dynamics in Higher Education: Expectations, Developments and Outcomes, transcript-verlag. Pp. 30I-328.

DIXIT, A.K. (1998), "The making of economic policy: A transition-cost politics perspective" - Munich lectures in economics, Cambridge: MIT Press.

ERNST, D. and Kim. L. (2002), Global production networks, knowledge diffusion, and local capability formation. Research Policy, 31, 8-9, pp. I4I7-I429.

EASTERLY.W. (20I3),"The tyranny od experts - economists, dictators and the forgotten rights of the poor", Basic Books, New York.

FINGLETON, E. (1999), "In Praise of Hard Industries", Buttonwood Press.

GALBRAITH, J. (20I2), "Inequality and instability - a study of the world economy just before the great crisis", Oxford University Press.

GILLIOT, D. (200I), Incentives in academia In Dewatripont Mathias, Thys-Clemenat, Françoise, and Wilkin, Luc, The Strategic Analysis of Universities: Microeconomic and Management Perspecfi es, Brussels, Editions de L' Université de Bruxelles, pp. 57-7I.

GHANI, E., Kharas, H. (2010), "The Service Revolution", Economic Premise, The World Bank, May 2010

HEITOR, M. V. (2008), A system approach to tertiary education institutions: towards knowledge networks and enhanced societal trust. Science and Public Policy, 35, 8, pp. 607-617.

HEITOR, M.V. (2014), How far university global partnerships may facilitate a new era of international affairs and foster political and economic relations?, Technological Forecasting and Social Change, acceptted to publication.

HEITOR, M. and Bravo, M. (20I0), Portugal on the crosstalk of change, facing the shock of the new: People, knowledge and ideas fostering the social fabric to facilitate the concentration of knowledge integrated commun, H.ities. Technological Forecasting and Social Change, 77, pp. 218-247.

HEPBURN, D. (20II), "Mapping the World's Changing Industrial Landscape", The World's Industrial Transformation Series, IEWIT BP 20I I/0I, Chatham House, July 201 I.
HIDALGO, C. A., Hausmann, R. (2009), "The building blocks of economic complexity", Proceedings of the National Academy of Sciences of the United States of America, vol. 106, no. 26, 10570-10575, 30 June 2009

HORTA, H. (2010), The role of the state in the internationalization of universities in catching-up countries: An analysis of the Portuguese higher education system. Higher Education Policy, 23, pp. 63-8I.

HORTA, H. (2009), Global and national prominent universities: internationalization, competitiveness and the role of the state. Higher Education, 58, 3, pp. 387-405.

LOCKE, R.M., and Wellhausen, R.L. (2014), "Production in the innovation economy", Cambridge: MIT Press

LUNDVALL, B.-Å., (1992), National Systems of Innovation: Towards a Theory of Innovation and Interactive Learning, London: Pinter Publishers, 1992.

KIM, H. E., and Zhu, M. (20I0), Universities as Firms: The case of US Overseas Programs in Clotfelter, Charles T. (Ed.), American Universities in a Global Market, Chicago, Chicago University Press, pp. 163-20I.

KNIGHT, J. (20II), Education Hubs: A Fad, a Brand, an Innovation? Journal of Studies in International Education, I5, 3, pp. $22 \mathrm{I}-240$.

MARGINSON, S. (2004), Competition and Markets in Higher Education: a 'glonacal' analysis. Policy Futures in Education, 2, 2, pp. 175-244.

MARSH, H. W. (2007), Students' evaluations of university teaching:A multidimensional perspective In Raymond P. Perry and John C. Smart (Eds.), The scholarship of teaching and learning in higher education:An evidence based perspective, New York: Springer, pp. 319-384

MAZZUCATO, M. (2013), "The Entrepreneurial State Debunking Public vs. Private Sector Myths", Anthem Press, London.

MICHALKO, M. (20II), "Creative Thinkering - putting your imagination to work”, New York Library, New York.

MCKINSEY Global Institute (20I2), "Manufacturing the future: The next era of global growth and innovation"; November.

NAIRN, A. (2002), "Engines that move markets”, John Wiley and Sons. 
NAE (2003), "The Impact of Academic Research on Industrial Performance", National Academy of Engineering, Washington: NAE Press.

NEAVE, G. (1995), The stirring of the prince and the silence of the lambs: the changing assumptions beneath higher education policy, reform and society in Dill, David D. and Sporn, Barbara (Eds) Emerging Patterns of Social Demand and University Reform: Through a Glass Darkly. Oxford, Pergamon. Pp. 54-7I.

NELSON, R.R. (ed.) (1993), National Innovation Systems. A Comparative Analysis, Oxford University Press, New York/ Oxford.

NELSON, R. R. (2004), The market economy, and the scientific commons Research Policy, 33, pp. 455-47I.

NOWOTNY, H., Scott, P. and Gibbons, M. (2003), Mode 2' Revisited:The New Production of Knowledge. Minerva, 4I, pp. 179-194.

OSTRY, S. and Nelson, R. (1995), "Techno-nationalism and techno-globalism: conflict and cooperation”, The Brookings Institution, Washington.

RELMAN, A. S. (1990), Peer review in scientific journalsWhat good is it? Western Journal of Medicine, I53, pp. 520522

ROBERTS, J. T. and Hite, A.B. (2007), "The globalization and development reader: Perspectives on development and global change", Malden: Blackwell

ROSENBERG, N., (2002), Knowledge and Innovation for Economic Development: Should Universities be Economic Institutions? in Conceição, Pedro, Gibson, David V., Heitor, ManuelV., Sirilli, Giorgio, and Veloso, Francisco M., Knowledge for Inclusive Development, Westport: Quorum. Pp. 35-47.

SALLES-FILHO, S., Avila, F.D., Sepulveda, J. and Colugnati, F.A.B.(2010), Multidimensional assessment of technology and innovation programs: the impact evaluation of INCAGROPeru. Research Evaluation, v. 19, p. I.

SAXENIAN, A. (1986), "Regional Advantage: Culture and Competition in Silicon Valley and Route 128", Cambridge: Harvard University Press.

SCHLOEGL, C., Gorraiz, J., Bart, C. and Bargmann, M. (2003), Evaluating two Australian university departments: Lessons learned. Scientometrics, 56, 3, pp. 287-299.
TUNG, R. L. (2008), Brain circulation, diaspora, and international competitiveness. European Management Journal, 26, pp. 298-304.

UNESCO (2010), Science Report 2010, Unesco, Paris

VEST, C. M. (2007), "The American Research University from World War II to World Wide Web: Governments, the Private Sector and the emerging Meta-University”, Berkeley: University of California Press.

ZIMAN, J. (1968), Public Knowledge: The Social Dimension of Science, Cambridge University Press

ZIMAN, J. (1978), Reliable Knowledge: an exploration of the grounds for belief in science, Cambridge University Press Ziman, J. (2000), Real Science: What it is, and what it means, Cambridge University Press 